\title{
PENINGKATAN SCIENCE PROCESS SKILLS DAN SIKAP ILMIAH PADA PEMBELAJARAN FISIKA MELALUI IMPLEMENTASI CTL
}

\author{
${ }^{1}$ Ana Silfiani Rahmawati1) \\ 2Yasinta Embu Ika') \\ 1anarahmawati734@gmail.com \\ 1Universitas Flores \\ 2ikayasinta223@gmail.com \\ 2Universitas Flores
}

\begin{abstract}
Abstrack
This study aims to find out the improvement of the science of process skills and scientific attitude of students through the implementation of Contextual Teaching and Learning (CTL). This research used in this study is Classroom action research using the Kemmis \& Mc Taggart model which consist of two cycles each cycle through the stages of planning, implementation, observation and reflection. The result of this study shows that the implementation of learning in cycle II was more increased compared to the learning process in cycle I. this is indicated by the value of N-Gain Sciences process skills in the first cycle of 0.432 while in the second cycle increased to 0.70; and N-Gain for scientific attitudes in cycle I was 0.252 while in cycle II it increased to 0.392 .
\end{abstract}

Keywords: Sciences Process Skills, saintific attitude, and CTL

\begin{abstract}
Abstrak
Penelitian ini bertujuan untuk mengetahui peningkatan Sciences Process Skill dan Sikap Ilmiah peserta didik melalui implementasi Contextual Teaching and Learning (CTL). Penelitian ini merupakan penelitian tindakan kelas (PTK) menggunakan model Kemmis \& Mc Taggart dengan pelaksanaan siklus sebanyak dua kali masing-masing siklus melalui tahap perencanaan, pelaksanaan, pengamatan dan refleksi. Hasil penelitian menunjukkan bahwa pelaksanaan pembelajaran pada siklus II lebih meningkat dibandingkan dengan proses pembelajaran pada siklus I. Hal ini ditunjukkan dengan nilai $\mathrm{N}$-Gain sciences process skill pada siklus I sebesar 0.432 sedangkan pada siklus II meningkat menjadi 0.70; dan N-Gain untuk sikap ilmiah pada siklus I sebesar 0.252 sedangkan pada siklus II meningkat menjadi 0.392 .
\end{abstract}

Kata kunci: sciences process skill, sikap ilmiah, dan CTL 


\section{PENDAHULUAN}

Dalam keseluruhan upaya pendidikan, proses belajar mengajar merupakan aktivitas yang paling penting, karena melalui proses inilah tujuan pendidikan akan dicapai. Dalam bidang pendidikan, tujuan-tujuan yang dirumuskan mengindikasikan apa yang kita ingin para siswa mempelajarinya. Tujuan (objective) yang ditetapkan guru ini bisa bersifat eksplisit atau implisit, mudah dipahami atau tersamar, mudah atau sulit diukur. Tujuan-tujuan ini bisa disebut dengan istilah-istilah. Dahulu, tujuan ini disebut aim, purpose, goal dan guiding out-come (Bobbitt, 1918 ; Rugg, 1926) dan b). Sekarang, tujuan-tujuan tersebut dianggap sebagai standar isi atau standar kurikulum (Kendall dan Marzano, 1996 ; Glatthorn, 1998) atau kompetensi peserta didik.

Tercapainya tujuan pendidikan di atas, akan ditentukan oleh berbagai unsur yang menunjangnya. Makmun (1996: 3-4) menyatakan tentang unsur-unsur yang terdapat dalam proses belajar mengajar yaitu : 1) Siswa, dengan segala karakteristiknya yang berusaha untuk mengembangkan dirinya seoptimal mungkin melalui kegiatan belajar; 2) Tujuan, ialah segala sesuatu yang diharapkan setelah adanya kegiatan belajar mengajar; 3) Guru, selalu mengusahakan terciptanya situasi yang tepat (mengajar) sehingga memungkinkan bagi terjadinya proses pengalaman belajar. Guru sebagai salah satu unsur dalam proses belajar mengajar memiliki multi peran, tidak hanya sebagai "pengajar" yang melakukan transfer of knowledge, tetapi juga sebagai pembimbing yang mendorong potensi, mengembangkan alternatif, dan memobilisasi siswa dalam belajar. Upaya peningkatan proses pendidikan di sekolah salah satunya adalah dengan melaksanakan kegiatan pembelajaran yang sesuai, baik dan terencana. Agar tujuan pembelajaran dapat tercapai, hal-hal yang harus dilakukan misalnya dengan menggunakan metode atau pendekatan pembelajaran yang sesuai dengan pembelajaran.

Fisika sebagai salah satu unsur dalam IPA mempunyai peranan yang sangat penting dalam pengembangan ilmu pengetahuan dan teknologi. Oleh karena itu dalam memacu ilmu pengetahuan dan teknologi keberhasilan proses pembelajaran fisika merupakan salah satu hal yang didambakan dalam peningkatan proses pendidikan di sekolah. Kenyataannya kualitas proses pembelajaran fisika di sekolah masih menekankan pada pemberian teori, pemberian contoh, dan pengerjaan soal oleh siswa. Hal ini cenderung membuat siswa hanya terpaku pada apa yang diberikan oleh guru dan menganggap guru adalah sumber utama pembelajaran, sehingga siswa belum bisa membangun pengetahuannya sendiri. Kurangnya pemahaman siswa terhadap teori atau konsep dan kondisi pembelajaran yang kurang memperhatikan keaktifan siswa juga menjadi penyebab umum rendahnya mutu pendidikan fisika di sekolah.

Untuk mengatasi permasalahan ini, tentunya perlu dilakukan pembelajaran yang sistematik. Guru diharapkan mampu menerapkan strategi, model dan metode yang tepat dan sesuai untuk pembelajaran fisika. Salah satu upaya guru dalam strategi pembelajaran adalah menggunakan model pembelajaran yang tepat dan sesuai dengan materi yang diajarkan. Hal ini dapat menunjang terciptanya kegiatan pembelajaran yang menjadikan siswa aktif dan dapat menyenangi mata pelajaran 
fisika, sehingga sikap mereka akan tumbuh terhadap fisika dan juga diharapkan dapat meningkatkan pemahaman siswa terhadap konsep yang dipelajari.

Materi-materi dalam pembelajaran fisika tidak terlepas dari gejala-gejala alam, sehingga diperlukan komunikasi antara siswa dan guru, agar siswa dapat menginformasikan pengalamannya tentang gejala-gejala alam tersebut. Hal ini juga dapat membantu siswa dalam memahami konsep-konsep dan mengkaji gejala-gejala alam tersebut. Pendekatan CTL merupakan konsep belajar yang dapat membantu guru mengaitkan antara materi yang diajarkan dengan situasi dunia nyata dan mendorong siswa membuat hubungan antara pengetahuan yang dimiliki dengan penerapannya dalam kehidupan sehari-hari. Dengan konsep ini diharapkan hasil pembelajaran lebih bermakna bagi siswa. Siswa akan menyadari bahwa pentingnya menguasai kompetensi yang telah ditetapkan dalam kurikulum karena sangat bermanfaat dalam kehidupan, oleh sebab ini maka peneliti tertarik untuk meneliti tentang peningkatan science process skills, dan sikap ilmiah pada pembelajaran fisika melalui implementasi CTL.

Pendidikan IPA diarahkan untuk mencari tahu dan berbuat sehingga dapat membantu peserta didik untuk memperoleh pemahaman yang lebih mendalam tentang alam sekitar (BSNP,2006:159). Depdiknas (2007:8) menyatakan bahwa hakikat IPA meliputi empat unsur yaitu : 1) Produk: berupa fakta, prinsip, teori dan hukum; 2) Proses: prosedur pemecahan masalah melalui metode ilmiah, metode ilmiah meliputi pengamatan, penyusunan hipotesis, perancangan eksperimen, percobaan atau penyelidikan, pengujian hipotesis melalui eksperimentasi, evaluasi, pengukuran, dan penarikan kesimpulan; 3) Aplikasi: penerapan metode atau kerja ilmiah dan konsep IPA dalam kehidupan sehari-hari; 4) Sikap: rasa ingin tahu tentang objek, fenomena alam, makhluk hidup, serta hubungan sebab akibat yang menimbulkan masalah baru yang dapat dipecahkan melalui prosedur yang benar.

Menggunakan keterampilan proses dalam pembelajaran sains membuat siswa belajar proses dan produk sekaligus. Keterampilan proses sains tidak dapat terpisahkan dari kegiatan yang berhubungan dengan sains. Hal ini sesuai dengan pernyataan Keil, Haney \& Zoffel (2009:4): "Science process skills are inseparable from the practice of science and play a key role in both formal and informal learning of science content", artinya keterampilan proses sains tidak dapat dipisahkan dari pelaksanaan sains dan mempunyai peran penting pada pembelajaran sains baik formal maupun nonformal. Hal senanda juga dikemukakan oleh Chiapetta \& Koballa (2010: 132) bahwa keterampilan proses sains terbagi menjadi dua yaitu keterampilan proses dasar (basic process skill) dan keterampilan proses integrasi (integrated process skill). Keterampilan proses sains dapat dilihat pada Tabel 1.

Tabel 1. Keterampilan Proses Sains (Science Process Skills)

\begin{tabular}{|c|c|}
\hline Proses Skill & Definisi \\
\hline $\begin{array}{l}\text { Keterampilan } \\
\text { Dasar }\end{array}$ & \\
\hline Mengamati & $\begin{array}{l}\text { Menggunakan alat indera untuk mengenali alat } \\
\text { dan bahan yang akan digunakan, dan mengenali } \\
\text { sifat-sifat benda. }\end{array}$ \\
\hline
\end{tabular}




\begin{tabular}{|c|c|}
\hline Proses Skill & Definisi \\
\hline $\begin{array}{l}\text { Keterampilan } \\
\text { Dasar }\end{array}$ & \\
\hline Mengklasifikasi & $\begin{array}{l}\text { Mengelompokkan sifat atau atribut sesuai } \\
\text { dengan golongannya. }\end{array}$ \\
\hline $\begin{array}{l}\text { Memanfaatkan } \\
\text { waktu }\end{array}$ & $\begin{array}{l}\text { Memvisualisasikan dan memanipulasi peristiwa } \\
\text { yang berkaitan dengan bentuk, waktu, jarak, dan } \\
\text { kecepatan }\end{array}$ \\
\hline $\begin{array}{l}\text { Menggunakan } \\
\text { perhitungan }\end{array}$ & Melakukan perhitungan secara kuantitaif. \\
\hline Menghitung & $\begin{array}{l}\text { Menuliskan jumlah objek atau zat secara } \\
\text { kuantitatif sesuai dengan satuannya. }\end{array}$ \\
\hline Menyimpulkan & Menuliskan kesimpulan dari hasil yang diperoleh \\
\hline Memprediksi & $\begin{array}{l}\text { Meramalkan suatu kejadian yang belum terjadi } \\
\text { melalui observasi }\end{array}$ \\
\hline $\begin{array}{l}\text { Keterampilan } \\
\text { Integrasi }\end{array}$ & $\begin{array}{l}\text { Memberikan penjelasan untuk objek atau } \\
\text { peristiwa tertentu }\end{array}$ \\
\hline $\begin{array}{l}\text { Mendefinisikan } \\
\text { operasional }\end{array}$ & $\begin{array}{l}\text { Mengembangkan pernyataan yang menyajikan } \\
\text { deskripsi konkret dari suatu obyek atau kejadian } \\
\text { dengan menyatakan apa yang harus dilakukan } \\
\text { pengamat. }\end{array}$ \\
\hline Merumuskan data & $\begin{array}{l}\text { Menyajikan data dalam bentuk gambar, atau } \\
\text { rumus matematika untuk memberikan } \\
\text { penjelasan. }\end{array}$ \\
\hline $\begin{array}{l}\text { Mengontrol } \\
\text { variabel }\end{array}$ & $\begin{array}{l}\text { Memanipulasi dan mengendalikan sifat yang } \\
\text { berhubungan dengan situasi atau aktivitas yang } \\
\text { menyebabkan sebab-akibat }\end{array}$ \\
\hline $\begin{array}{l}\text { Meginterpretasikan } \\
\text { data }\end{array}$ & $\begin{array}{l}\text { Menyampaikan penjelasan, kesimpulan, atau } \\
\text { hipotesis dari data yang telah disusun. }\end{array}$ \\
\hline Membuat hipotesis & $\begin{array}{l}\text { Mengeneralisasi pengamatan atau kesimpulan } \\
\text { yang dapat digunakan untuk menjelaskan topik } \\
\text { yang luas. }\end{array}$ \\
\hline Bereksprimen & $\begin{array}{l}\text { Menguji hipotesis melalui manipulasi dan } \\
\text { pengendalian variabel independen kemudian } \\
\text { menafsirkan dan menyajikan hasil dalam bentuk } \\
\text { laporan. }\end{array}$ \\
\hline
\end{tabular}

Sikap merupakan produk dari kegiatan belajar. Sikap diperoleh melalui proses seperti pengalaman, pembelajaran, identifikasi, perilaku peran (guru-murid, orang tua-anak). Aspek-aspek sikap ilmiah yang dikembangkan dalam pembelajaran sains dapat dilihat pada Tabel 2.

Tabel 2. Dimensi dan Indikator Sikap Ilmiah

\begin{tabular}{c|l|l}
\hline No. & \multicolumn{1}{|c|}{ Dimensi } & Indikator \\
\hline 1. & Sikap ingin tahu & Antusias mencari jawaban \\
\hline
\end{tabular}




\begin{tabular}{|c|c|c|}
\hline No. & Dimensi & Indikator \\
\hline & & $\begin{array}{l}\text { Perhatian pada objek yang diamati } \\
\text { Antusias pada proses sains } \\
\text { Menanyakan setiap langkah kegiatan }\end{array}$ \\
\hline 2. & $\begin{array}{ll}\text { Sikap } & \text { respek } \\
\text { terhadap data/fakta }\end{array}$ & $\begin{array}{l}\text { Objektif/jujur } \\
\text { Tidak memanipulasi data } \\
\text { Mengambil keputusan sesuai fakta } \\
\text { Tidak mencampur fakta dengan pendapat }\end{array}$ \\
\hline 3. & Sikap berpikir kritis & $\begin{array}{l}\text { Meragukan temuan teman } \\
\text { Menanyakan setiap perubahan/hal baru } \\
\text { Mengulangi kegiatan yang dilakukan } \\
\text { Tidak mengabaikan data meskipun kecil }\end{array}$ \\
\hline 4. & $\begin{array}{l}\text { Sikap penemuan dan } \\
\text { kreativitas }\end{array}$ & $\begin{array}{l}\text { Menggunakan fakta-fakta untuk dasar } \\
\quad \text { konklusi } \\
\text { Menunujukkan laporan yang berbeda } \\
\text { dengan teman kelas } \\
\text { Merubah pendapat dalam merespon } \\
\text { terhadap fakta } \\
\text { Menggunakan alat tidak seperti biasanya } \\
\text { Menyarankan percobaan-percobaan baru } \\
\text { Menguraikan konklusi baru hasil } \\
\text { pengamatan }\end{array}$ \\
\hline 5. & $\begin{array}{lr}\text { Sikap } & \text { berpikiran } \\
\text { terbuka } & \text { dan } \\
\text { kerjasama } & \end{array}$ & $\begin{array}{l}\text { Menghargai pendapat/temuan orang lain } \\
\text { Mau merubah pendapat jika data kurang } \\
\text { Menerima saran dari teman } \\
\text { Tidak merasa selalu benar } \\
\text { Menganggap setiap kesimpulan adalah } \\
\text { tentatif } \\
\text { Berpartisipasi aktif dalam kelompok }\end{array}$ \\
\hline 6. & Sikap ketekunan & $\begin{array}{l}\text { Melanjutkan meneliti sesudah } \\
\text { "kebaharuannya" hilang } \\
\text { Mengulangi percobaan meskipun } \\
\text { berakibat gagal } \\
\text { Melengkapi satu kegiatan meskipun } \\
\text { teman kelasnya selesai lebih awal }\end{array}$ \\
\hline 7. & $\begin{array}{l}\text { Sikap peka terhadap } \\
\text { lingkungan sekitar }\end{array}$ & $\begin{array}{l}\text { Perhatian terhadap sekitar } \\
\text { Partisipasi pada kegiatan sosial } \\
\text { menjaga kebersihan lingkungan sekolah }\end{array}$ \\
\hline
\end{tabular}

Pembelajaran kontekstual (Contextual Teaching and Learning) merupakan konsep belajar yang dapat membantu guru mengaitkan antara materi yang diajarkan dengan situasi dunia nyata siswa dan mendorong siswa membuat hubungan antara pengetahuan yang dimilikinya dengan penerapannya dalam kehidupan mereka sebagai anggota keluarga dan masyarakat (Nurhadi, 2002). Menurut Johnson (2002) "Contextual teaching and learning enables students to connect the content of academic subject with the immediate context of their daily lives to discover meaning. It enlarges 
their personal context furthermore, by providing students with fresh experience that stimulate the brain to make new connection and consecuently, to discover new meaning". Sedangkan Howey R, Kenneth, (2001) mendefenisikan CTL sebagai berikut : "Contextual teaching is teaching that enables learning in which student employ their academic understanding and abilities in a variety of in - and out of school context to solve simulated or real world problems, both alone and with others".

Komponen pembelajaran kontekstual (Johnson Elaine B, 2002) meliputi:

1. Menjalin hubungan-hubungan yang bermakna (making meaningfull connections)

2. Mengerjakan pekerjaan-pekerjaan yang berarti (doing significant work)

3. Melakukan proses belajar yang diatur sendiri (self-regulated learning)

4. Mengadakan kolaborasi (collaborating)

5. Berpikir kritis dan kreatif (critical and creative thinking)

6. Memberikan layanan secara individual (nurturing the individual)

7. Mengupayakan pencapaian standar yang tinggi (reaching high standards), dan

8. Menggunakan asesmen autentik (using authentic assessment)

Penelitian tentang penerapan pembelajaran CTL sudah banyak dilakukan oleh peneliti-peneliti sebelumnya. Adapun diantaranya adalah :

1. Penelitian Sugeng Widadi (2009) menunjukkan bahwa ada perbedaan yang signifikan antara pembelajaran CTL dan konvensional terhadap kemampuan pemahaman dan penerapan konsep sains dan ada perbedaan yang signifikan antara pembelajaran CTL dan konvensional terhadap kualitas proses pembelajaran sains.

2. Penelitian Sukardi Abbas (2010) menunjukkan bahwa dengan menggunakan pendekatan kontekstual di SMP Negeri 2 kota ternate dapat meningkatkan prestasi belajar sains siswa.

3. Penelitian Lulul Widhi Martanti (2012) menunjukkan bahwa penerapan pendekatan CTL dapat meningkatkan keterampilan proses sains dan meningkatkan sikap ilmiah siswa kelas X SMA Negeri 1 Pleret.

\section{METODE PENELITIAN}

Jenis penelitian ini merupakan penelitian tindakan kelas (Classroom Action Research). Tujuan dari penelitian ini adalah untuk meningkatkan science process skills dan sikap ilmiah siswa pada pembelajaran fisika melalui implementasi CTL. Desain penelitian yang digunakan pada penelitian ini adalah model yang dikemukakan oleh Kemmis \& Mc Taggart. Adapun model yang dimaksud dapat digambarkan sebagai berikut :

\section{SIKLUS I}

\section{Perencanaan $\longrightarrow$ Pelaksanaan}




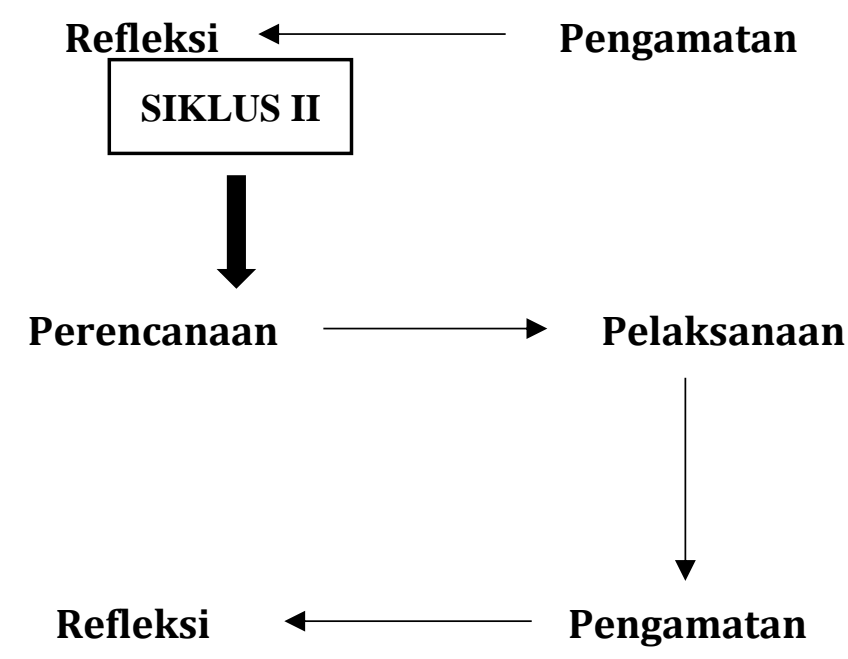

Gambar 1. Rancangan Penelitian Tindakan Kelas

\section{Teknik Pengumpulan Data}

Teknik pengumpulan data pada penelitian ini adalah dengan tes dan non tes. Pengumpulan data menggunakan teknik tes berupa soal pilihan ganda yang sudah baku atau dibakukan oleh para ahli, sedangkan teknik non tes yang digunakan dalam penelitian ini berupa observasi, angket/kuesioner, wawancara dan dokumentasi.

\section{Teknik Analisis Data}

Setelah data diperoleh melalui penelitian, selanjutnya dianalisis karena data yang diperoleh belum memberikan arti yang sebenarnya.

1. Analisis Deskriptif

Statistik deskriptif digunakan untuk menyajikan data yang telah diperoleh dengan tanpa menggeneralisasi hasil dari penelitian tersebut. Analisis deskriptif digunakan untuk menyajikan data yang telah diperoleh melalui pretest dan posttest pada kelas eksperimen.

2. Uji asumsi analisis data

Teknik analisis data yang digunakan pada penelitian ini adalah uji asumsi . Uji persyaratan yang dipakai untuk menganalisis terdiri dari uji normalitas dan uji homogenitas.

3. Uji hipotesis

Pengujian hipotesis menggunakan uji manova atau Multivariate Analysis of Variance. Multivariate Analysis of Variance (MANOVA) digunakan untuk membuktikan secara signifikan pengaruh implementasi CTL terhadap Science Process Skills dan sikap ilmiah pada pembelajaran fisika di SMA Negeri 1 Ende, Propinsi Nusa Tenggara Timur (NTT). Adapun hipotesis yang diajukan sebagai berikut:

$$
\begin{aligned}
& \mathrm{H}_{\mathrm{o}}:\left(\begin{array}{l}
\mu A 1 \\
\mu A 2
\end{array}\right)=\left(\begin{array}{l}
\mu K 1 \\
\mu K 2
\end{array}\right) \\
& \mathrm{H}_{\mathrm{a}}:\left(\begin{array}{l}
\mu A 1 \\
\mu A 2
\end{array}\right) \neq\left(\begin{array}{l}
\mu K 1 \\
\mu K 2
\end{array}\right)
\end{aligned}
$$




\section{HASIL DAN PEMBAHASAN \\ Deskripsi Hasil Penelitian}

Deskripsi data merupakan gambaran data yang diperoleh untuk mendukung pembahasan hasil penelitian. Data yang diperoleh dalam penelitian ini akan memberikan gambaran terhadap kondisi awal dan kondisi akhir dari setiap variabel. Data yang akan dipakai untuk mendeskripsikan tersebut terdiri dari data posttest dari sciences process skiils dan sikap ilmiah, sedangkan data pretest hanya sebagai penunjang. Penelitian ini dilaksanakan pada kelas XI MIPA 1 SMA Negeri 1 Ende penelitian ini dilakukan selama kurang lebih 3 bulan yang dimulai dari bulan Februari 2018 sampai Mei 2018. Subjek penelitian sebanyak 33 orang. Pelaksanaan penelitian ini dilakukan sebanyak dua siklus, yaitu siklus I dan siklus II. Setiap siklus dilaksanakan dengan empat kali pertemuan, sehingga dua siklus tersebut dilaksanakan sebanyak delapan kali pertemuan. Dari kedua siklus tersebut diperoleh data sejauh mana peningkatan sciences process skills dan sikap ilmiah dari peserta didik melalui model Contextual Teaching and Learning (CTL). Pada akhir tiap siklus diberikan evaluasi dan refleksi yang berkaitan dengan sciences process skills peserta didik.

\section{a) Hasil Siklus 1}

a. Sciences Process Skills

Hasil posttest untuk Sciences Process Skills pada siklus I, dapat dilihat pada Tabel 3.

Tabel 3. Hasil Posttest SPS Siklus I

\begin{tabular}{lr}
\hline \multicolumn{2}{c}{ Statistics } \\
\hline posttest1 \\
\hline $\mathrm{N}$ & Valid \\
\cline { 2 - 2 } Missing & 33 \\
\hline Mean & 12.0000 \\
\hline Median & 12.0000 \\
\hline Mode & 12.00 \\
\hline Std. Deviation & 1.63936 \\
\hline Variance & 2.688 \\
\hline Minimum & 9.00 \\
\hline Maximum & 15.00 \\
\hline Sum & 396.00 \\
\hline
\end{tabular}

Dari hasil statistik di atas dapat dilihat bahwa pada posttest siklus 1 jumlah skornya adalah 396.00 dengan nilai minimum adalah 9.00 sedangkan nilai maksimum adalah 15.00 .

b. Sikap Ilmiah

Untuk hasil posttest sikap ilmiah pada siklus I dapat dilihat pada Tabel 4. 
Tabel 4. Hasil Posttest SI Siklus I

\begin{tabular}{|c|c|c|}
\hline \multicolumn{3}{|c|}{ Statistics } \\
\hline \multicolumn{3}{|c|}{ posttestSI1 } \\
\hline \multirow[t]{2}{*}{$\mathrm{N}$} & Valid & 33 \\
\hline & Missing & 0 \\
\hline \multicolumn{2}{|c|}{ Mean } & 25.3030 \\
\hline \multicolumn{2}{|c|}{ Median } & 25.0000 \\
\hline \multicolumn{2}{|c|}{ Mode } & 28.00 \\
\hline \multicolumn{2}{|c|}{ Std. Deviation } & 2.51849 \\
\hline \multicolumn{2}{|c|}{ Variance } & 6.343 \\
\hline \multicolumn{2}{|c|}{ Minimum } & 22.00 \\
\hline \multicolumn{2}{|c|}{ Maximum } & 30.00 \\
\hline \multicolumn{2}{|c|}{ Sum } & 835.00 \\
\hline
\end{tabular}

Dari hasil statistik di atas dapat dilihat bahwa pada posttest sikap ilmiah pada siklus I jumlah skornya adalah 835.00 dengan nilai minimum adalah 22.00 sedangkan nilai maksimum adalah 30.00

b) Hasil siklus II

a. Sciences Process Skills

Untuk hasil posttest Sciences Process Skills pada siklus II dapat dilihat pada Tabel 5.

Tabel 5. Hasil Posttest SPS siklus II

\begin{tabular}{|c|c|c|}
\hline \multicolumn{3}{|c|}{ Statistics } \\
\hline & $\begin{array}{c}\text { Kode } \\
\text { PD }\end{array}$ & $\begin{array}{l}\text { Posttest } \\
\text { Siklus II }\end{array}$ \\
\hline Valid & 33 & 33 \\
\hline Missing & 0 & 0 \\
\hline Mean & & 16.1818 \\
\hline Median & & 16.0000 \\
\hline Std. Deviation & & 1.66686 \\
\hline Variance & & 2.778 \\
\hline Minimum & & 12.00 \\
\hline Maximum & & 19.00 \\
\hline Sum & & 534.00 \\
\hline
\end{tabular}

Dari hasil statistik di atas dapat dilihat bahwa pada posttest Sciences Process Skills pada siklus II jumlah skornya adalah 534.00 dengan nilai minimum adalah 12.00 sedangkan nilai maksimum adalah 19.00 . 


\section{b. Sikap ilmiah}

Untuk hasil posttest sikap ilmiah pada siklus II dapat dilihat pada Tabel 6.

Tabel 6. Hasil Posttest SI Siklus II

\begin{tabular}{|c|c|c|}
\hline \multicolumn{3}{|c|}{ Statistics } \\
\hline \multicolumn{3}{|c|}{ posttestSI2 } \\
\hline \multirow[t]{2}{*}{$\mathrm{N}$} & Valid & 33 \\
\hline & Missing & 0 \\
\hline \multicolumn{2}{|c|}{ Mean } & 36.7576 \\
\hline \multicolumn{2}{|c|}{ Median } & 36.0000 \\
\hline \multicolumn{2}{|c|}{ Mode } & 35.00 \\
\hline \multicolumn{2}{|c|}{ Std. Deviation } & 2.35890 \\
\hline \multicolumn{2}{|c|}{ Variance } & 5.564 \\
\hline \multicolumn{2}{|c|}{ Minimum } & 32.00 \\
\hline \multicolumn{2}{|c|}{ Maximum } & 40.00 \\
\hline \multicolumn{2}{|c|}{ Sum } & 1213.00 \\
\hline
\end{tabular}

Dari hasil statistik di atas dapat dilihat bahwa pada posttest sikap ilmiah pada siklus II jumlah skornya adalah 1213.00 dengan nilai minimum adalah 32.00 sedangkan nilai maksimum adalah 40.00 .

c) Siklus I dan siklus II

a. Sciences Process Skills

Secara umum hasil untuk Sciences Process Skills pada siklus I dan siklus II dapat dilihat pada data dibawah ini (Tabel 7).

Tabel 7. Hasil Siklus I dan II untuk SPS

\begin{tabular}{lrr}
\hline & \multicolumn{2}{c}{ Statistics } \\
\hline & Posttest I SPS & \multicolumn{1}{c}{ SPS } \\
\hline IValid & 33 & 33 \\
\hline Missing & 0 & 0 \\
\hline Mean & 12.0000 & 16.1818 \\
\hline Median & 12.0000 & 16.0000 \\
\hline Variance & 2.688 & 2.778 \\
\hline Minimum & 9.00 & 12.00 \\
\hline Maximum & 15.00 & 19.00 \\
\hline Sum & 396.00 & 534.00 \\
\hline
\end{tabular}

Dari data diatas dapat dilihat bahwa pada posttest siklus I nilai minimum, maksimum, mean, varians, dan jumlah skor peserta didik adalah 9.00; 15.00; 12.00; 2.688; dan 396.00, sedangkan pada posttest siklus II nilai minimum, 
maksimum, mean, variansi, dan jumlah skor peserta didik adalah 12.00; 19.00; 16.18; 2.77; dan 534.00. Hal ini menunjukkan adanya peningkatan Sciences Process Skills peserta didik pada siklus II jika dibandingkan dengan siklus I.

b. Sikap Ilmiah

Secara umum hasil untuk sikap ilmiah pada siklus I dan siklus II dapat dilihat pada data dibawah ini (Tabel 8).

Tabel 8. Hasil Siklus I dan II untuk SI

\begin{tabular}{lrr}
\hline \multicolumn{3}{c}{ Statistics } \\
\hline & $\begin{array}{c}\text { Posttest } \\
\text { I SI }\end{array}$ & $\begin{array}{r}\text { Posttest II } \\
\text { SI }\end{array}$ \\
\hline N Valid & 33 & 33 \\
\cline { 2 - 3 } Missing & 0 & 0 \\
\hline Mean & 25.3030 & 36.7576 \\
\hline Median & 25.0000 & 36.0000 \\
\hline Minimum & 22.00 & 32.00 \\
\hline Maximum & 30.00 & 40.00 \\
\hline Sum & 835.00 & 1213.00 \\
\hline
\end{tabular}

Dari data diatas dapat dilihat bahwa pada posttest siklus I nilai minimum, maksimum, mean dan jumlah skor peserta didik adalah 22.00; 30.00; 25.30; dan 835.00 sedangkan pada posttest siklus II nilai minimum, maksimum, mean, dan jumlah skor peserta didik adalah $32.00 ; 40.00 ; 36.75$; dan 1213.00. Hal ini menunjukkan adanya peningkatan sikap ilmiah peserta didik pada siklus II jika dibandingkan dengan siklus I.

c. Rata-rata Peningkatan ( $N$-Gain)

Rata-rata peningkatan ( $N$-Gain) untuk sciences process skills dan sikap ilmiah pada masing-masing siklus dapat dilihat pada Tabel 9:

Tabel 9. Tabel Peningkatan Rata-rata ( $N$-Gain)

\begin{tabular}{l|r|c|r|r|r|r}
\hline \multirow{2}{*}{ Tindakan } & \multicolumn{3}{|c|}{ Science Process Skills } & \multicolumn{3}{c}{ Sikap Ilmiah } \\
\cline { 2 - 7 } & Posttest & Gain & N-Gain & Posttest & Gain & N-Gain \\
\hline Siklus I & 12 & 6.242 & 0.432 & 25.303 & 12.09 & 0.252 \\
\hline Siklus II & 16.181 & 9.181 & 0.7 & 36.757 & 15.06 & 0.392 \\
\hline
\end{tabular}

Dari tabel dapat dilihat bahwa pada siklus II peserta didik mengalami peningkatan yang signifikan jika dibandingkan dengan tindakan pada siklus II.

d) Hasil Uji Hipotesis

\section{a. Uji prasyarat analisis}

1) Uji Normalitas

hasil uji normalitas sciences process skills dan sikap ilmiah peserta didik pada siklus I dan siklus II dapat dilihat pada Tabel 10. 



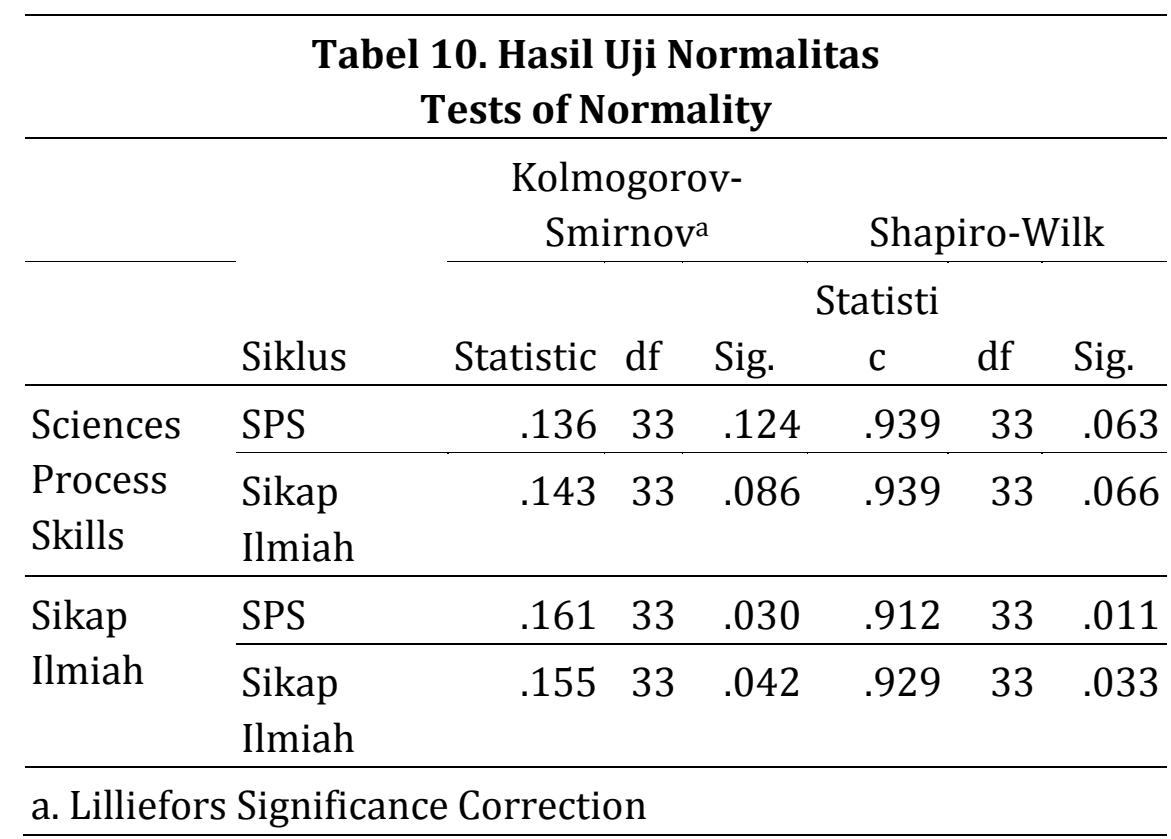

Tabel menunjukkan bahwa nilai signifikansi uji normalitas dari masingmasing variabel adalah melebihi 0.05. Dengan demikian, diperoleh keputusan bahwa $\mathrm{H}_{\mathrm{o}}$ diterima, maka sampel dalam penelitian ini berdistribusi normal.

\section{2) Uji Homogenitas}

Uji homogenitas contextual teaching and learning (CTL) terhadap sciences process skills dan sikap ilmiah secara bersama-sama dapat dilihat pada Tabel 11.

\begin{tabular}{lccccc}
\hline \multicolumn{5}{c}{$\begin{array}{c}\text { Tabel 11. Hasil Uji Homogenitas } \\
\text { Test of Homogeneity of Variances }\end{array}$} \\
& $\begin{array}{c}\text { Levene } \\
\text { Statistic }\end{array}$ & df1 & & df2 & Sig. \\
\hline & .102 & 1 & 64 & .750 \\
\hline $\begin{array}{l}\text { Sciences Process } \\
\text { Skills }\end{array}$ & & & & \\
\hline Sikap Ilmiah & .240 & 1 & 64 & .626 \\
\hline
\end{tabular}

Dari tabel di atas dapat dilihat bahwa hasil uji homogenitas melalui uji Lavene's Test untuk semua variabel memiliki nilai signifikansi lebih besar dari 0.05, sehingga dapat disimpulkan bahwa seluruh subjek penelitian adalah homogen.

b. Uji hipotesis

Hasil analisis statistik menggunakan uji manova atau multivariate Analysis of Variance dapat dilihat pada Tabel 12. 
Tabel 12. Hasil Uji Hipotesis

\begin{tabular}{c|c|r|r|c}
\hline \multicolumn{5}{c}{ Hotelling's T-Squared Test } \\
\hline $\begin{array}{c}\text { Hotelling's T- } \\
\text { Squared }\end{array}$ & $\mathrm{F}$ & $\mathrm{df1}$ & $\mathrm{df2}$ & Sig \\
\hline 81.385 & 81.385 & 1 & 32 & .000 \\
\hline
\end{tabular}

Dari tabel terlihat bahwa nilai signifikansi yang diperoleh adalah 0.000 dan bernilai lebih kecil dari 0.05. Dengan demikian, diperoleh keputusan bahwa $\mathrm{H}_{\mathrm{o}}$ ditolak, maka terdapat peningkatan yang signifikan.

\section{PEMBAHASAN}

Sekolah merupakan tempat berlangsungnya pembelajaran secara formal. Proses pembelajaran di sekolah berlangsung selama 7 sampai 9 jam setiap harinya. Berbeda dengan proses pembelajaran pada zaman dulu, pada masa sekarang proses pembelajaran bukanlah semata-mata hanya melafalkan materi dan mengerjakan tugas yang diberikan guru, melainkan keterlibatan peserta didik secara langsung sangat mempengaruhi jalannya pembelajaran. Guru sebagai salah satu unsur dalam proses pembelajaran bukan lagi sebagai pusat dari proses pembelajaran. Untuk menunjang proses pembelajaran, guru harus menerapkan model, strategi, ataupun pendekatan yang dapat menunjang proses pembelajaran, sehingga peserta didik tidak merasa jenuh dan bosan selama proses pembelajaran. CTL merupakan salah satu pendekatan pembelajaran yang mengaktifkan peserta didik dalam proses pembelajaran. Melalui CTL peserta didik dapat mengaitkan antara materi yang diajarkan dengan situasi dunia nyata dan mendorong peserta didik membuat hubungan antara pengetahuan yang dimiliki dengan penerapannya dalam kehidupan sehari-hari.

\section{a. Contextual Teaching and Learning terhadap Sciences Process Skills}

Penelitian pada siklus I dan II menunjukkan bahwa ada peningkatan yang dialami oleh peserta didik dari keterampilan dasar sampai keterampilan integritas. Keterampilan proses sains peserta didik pada materi suhu dan kalor sangat meningkat melalui implementasi CTL. Hal ini dapat dilihat melalui nilai setelah guru melakukan pembelajaran menggunakan model CTL, dimana nilai test akhir (posttest) pada siklus II lebih tinggi atau meningkat dibanding nilai pada test siklus I maupun nilai pra-test.

\section{b.Contextual Teaching and Learning terhadap Sikap Ilmiah}

Sikap ilmiah sangat dibutuhkan oleh peserta didik agar peserta didik dapat menjadi ilmuan yang kompeten. Dalam kehidupan sehari-hari, sikap ilmiah juga sangat penting diterapkan. Dalam proses pembelajaran pentingnya bersikap secara ilmiah dapat dilihat melalui proses pembelajaran, dimana harus saling menghormati antara peserta didik dengan peserta didik, peserta didik dengan guru, maupun antar sesama guru. Jujur, saling terbuka, dapat menerima pendapat orang lain, saling percaya, dan sikap ilmiah lainnya sangat penting dalam proses pembelajaran. Melalui pendekatan CTL, sikap ilmiah peserta didik dapat meningkat. Hal ini dapat dilihat dari nilai N-Gain sikap ilmiah yang meningkat pada siklus II. 


\section{c.Contextual Teaching and Learning terhadap Sciences Process Skill dan Sikap Ilmiah}

Proses pembelajaran sangat berpengaruh terhadap tingkat prestasi peserta didik. Pembelajaran Contextual Teaching and Learning (CTL) merupakan salah satu pembelajaran yang sangan dibutuhkan dewasa ini. Melalui CTL peserta didik dapat belajar sekaligus mengajar diri sendiri. Melalui CTL Sciences Process Skill dan Sikap Ilmiah peserta didik dapat meningkat secara signifikan, hal ini dapat dilihat dari nilai N-Gain kedua variabel ini. Pada siklus I N-Gain Sciences Process Skill sebesar 0.432 dan N-Gain Sikap Ilmiah sebesar 0.252, sedangkan pada siklus II N-Gain Sciences Process Skill sebesar 0.70 dan N-Gain Sikap Ilmiah sebesar 0.392. Dari data di atas dapat dilihat bahwa dari siklus I dan siklus II, baik Sciences Process Skill maupun sikap Ilmiah mengalami peningkatan yang signifikan

\section{Keterbatasan Penelitian}

Keterbatasan dalam penelitian ini sebagai berikut:

1. Kurangnya kerjasama antara peserta didik yang memiliki kemampuan tinggi dan peserta didik yang berkemampuan rendah

2. Keterbatasan alat praktikum

3. Jumlah soal latihan atau LKS kurang disesuaikan dengan alokasi waktu, sehingga ada beberapa soal yang belum dikerjakan

\section{SIMPULAN}

Berdasarkan hasil pengujian hipotesis dan pembahasan yang telah dipaparkan pada penelitian ini, maka dapat disimpulkan bahwa implementasi Contextual Teaching and Learning (CTL) dapat meningkatkan: (1) science process skills peserta didik; (2) sikap ilmiah peserta didik; dan (3) dapat meningkatkan science process skills dan sikap ilmiah peserta didik pada pembelajaran fisika.

\section{UCAPAN TERIMAKASIH}

Peneliti mengucapkan banyak terimakasih kepada semua pihak yang membantuk terselesaikannya penelitian ini, terutama pimpinan di Universitas Timor yang banyak memberika supot baik berupa moril dan materiil sehingga proses penelitian tindakan ini berjalan dengan baik, bapak observer yang telah banyak membantu selama proses penelitian yang banyak memberikan saran sehingga permasalahn-permasalahan yang yang ditemukan pada saat penelitian dapat terselesaikan dan terimakasih pula kepada semua dewan guru yang memberikan supot atas erselesaikannya penelitian ini. 


\section{DAFTAR PUSTAKA}

Abin, Syamsudin Makmun. (1996). Psikologi Pendidikan Perangkat Sistem Pengajaran Modul. Bandung: Remaja Rosdakarya

BSNP. (2006). Permendiknas RI No. 22 Tahun 2006 tentang Standar Isi untuk Satuan Pendidikan Dasar dan Menengah. Jakarta.

Bobbitt, F. (1918). The Curriculum. Boston: Houghton Mifflin

Chiappetta, E.L., \& Koballa, T.R. (2010). Science Instruction in The Middle and. Secondinary Schools Developing Fundamental Knowledge and Skills. USA

Depdiknas. (2007). Panduan Pengembangan Pembelajaran IPA Terpadu. Jakarta: Puskur, Balitbang Depdiknas

Glatthorn, Allan A. (1998). The Educational Imagination. New York: MacMillan Publishing Company

Johnson David W and Roger T. Johnson. (2002). Cooperative Learning Methode: A Meta-Analysis. Journal of Research in Education. http://www.eeraonline.org/journal/files/2002/JRE_2002_01_DWJohnson.p df

Johnson, Elaine B. PH.D. (2007). Contextual Teaching and Learning. Mizan Learning Center (MLC). Bandung.

Keil, C., Haney, J., \& Zoffel, J. (2009). Improvements in Student Achievement and Science Process Skills Using Environmental Health Science ProblemBased Learning Curricula. Journal of Education, 13(1), 1-18.

Marzano. RJ, and Kendall, J.S. (2008). Designing and Asessing Educational Objectives, California: Corwin Press

Nurhadi. (2002). Pendekatan kontekstual. Jakarta: Depdiknas.

Rugg (ed), (1926). The Foundation and Technique for Study of Education, Bloomington ind: Public Shool Puplishing, 